\title{
INVESTIGATING EXTERNAL DEBT AND EXCHANGE RATE FLUCTUATIONS IN NIGERIA: ANY DIFFERENCE WITH ARDL MODEL?
}

Timothy Ayomitunde ADEREMI

Bells University of Technology, Nigeria

\section{Lawrence Olusegun FAGBOLA}

Osun State University, Nigeria

Gbenro Matthew SOKUNBI

Michael Otedaola College of Primary Education, Nigeria

Chidinma Edith EBERE

Babcock University, Nigeria

\begin{abstract}
One of the contending issues in Nigeria in the recent time is external debt and exchange rate fluctuations. In view of the above, this study examined the relationship between external debt and exchange rate fluctuations in Nigeria over the period of 1981 to 2018. Consequently, the study employed Autoregressive Distribution Lag Model to address the objective of the study. The major findings that originated in this paper are as follows: external debt, debt service payment and foreign reserve have a significant positive impact on exchange rate fluctuations in the short run in Nigeria. Furthermore, based on these findings, recommendations are made for the policy makers that external debt as a means of financing budget deficit should be minimized if not totally discouraged in Nigeria because its servicing in particular and repayment put pressure on foreign exchange market in the short run and thereby leads to exchange rate fluctuations in terms of depreciation of naira in the country. Also, country's foreign reserve should be strengthened through the implementation of aggressive export promotion policy in Nigeria.
\end{abstract}

JEL classification: F3, F31

Keywords: Exchange Rate, Fluctuations, External Debt, ARDL, Nigeria.

\footnotetext{
${ }^{{ }^{*}}$ Corresponding author. Address: Department of Economics, Accounting and Finance, Bells University of Technology, km. 8, Idiroko Road, Benja Village, P.M.B. 1015, Ota, Nigeria, Email: taaderemi@bellsuniversity.edu.ng
} 


\section{Introduction}

External debt could be conceptualized as the resources sourced outside the shores of a country for investment projects, and this does not in any way come from any local citizens, whether corporate or individual. This is usually borrowed from foreign lenders such commercial banks, government or international financial institutions etc. Meanwhile, one of the critical challenges facing developing economies, Nigeria inclusive in the last few decades is debt crisis. The issues of debt crisis among developing economies have become a subject of concern to the multilateral borrowers and advanced economies (PNUD, 2011). This is because the majority of developing and emerging countries are constrained by savings, and this makes external debt as an inevitable source of capital for economic develop (Blessy and Lakshmi, 2020).

Meanwhile, the connection between the issue of external debt and other macroeconomic variables cannot be overemphasized in Nigeria because substantial economic growth registered in 1970 s was largely due to external debt as the country recorded persistent deficit in currents account which made it inevitable for the country to embark on huge borrowing from international money and capital market to augment payment gaps (Ayadi and Ayadi, 2008; Adepaju et al. 2007). However, external debt can be of a great contribution to the growth of economy if such loan is used to finance viable projects that have the capacity to yield an adequate rate of return. This variable can also bridge the gap that exists between domestic savings and investment in one hand and between exports and imports of goods and services on the other hand.

In the past few decades Nigeria has been bewildered with external debt problems. These problems arose from the inefficient use and control of borrowed funds, low returns to investments, inadequate policy framework for debt management and international developments in interest rates, terms of trade and trade policies and corruption. Historically, huge debts in Nigeria are connected with continued recklessness and selfishness of its leader. For instance, Nigeria had a debt stock of $\$ 1$ billion in 1971 , by 1991 , it had risen to $\$ 33.4$ billion. This story has not changed even to the recent time. From 2015 to 2018, Nigeria external debt profile has risen from $\$ 10.32$ billion to $\$ 22.08$ billion in 2018 (DMO, 2018). This implies that Nigeria's debt profile rose by $114.05 \%$ within three years of the last without corresponding infrastructural development in the country, rather than gluttonous desire of people at corridor of powers to obtain loans for the execution of white elephant projects in the country (Semenitari, 2005).

It is worth of note that huge debt incurred so far has constituted a worrisome burden in terms of its servicing to the country in such a way that country finds it difficult to ensure the welfare of its citizen. As a matter of fact, Nigeria paid about $\$ 4.9$ billion annually on debt servicing prior to the debt cancellation deal few years ago (Aluko and Arowolo, 2010). Consequently, it has been established in the literature that there is a link between external debt and exchange rate fluctuation because the multiplier effect of the Paris Club debt cancellation immediately led to noticeable appreciation of naira vis-à-vis the dollar from 132.1 Naira in 2005 to 128.6 in 2006. Also, naira in 2007, naira further appreciated to 125.8 Naira against $\$ 1$ and then 118.5 in 2008 (CBN 2010). 
However, the stability of macroeconomic variables like exchange rate and inflation rate are paramount indices that could sustain the use and repayment of external debt in the domestic economy. The advent of Structural Adjustment Programme in Nigeria in 1986, marked the significant genesis of overdependence of the Nigerian economy on the foreign capital in the forms of external debt to supplement saving-investment deficient gap in the country. It is not a gain to say that the demand for foreign currency poses corresponding effect on exchange rate of the domestic economy. It has been observed that within the period of post SAP era, exchange rate in Nigeria has been fluctuating by various degree of appreciation and depreciation vis-à-vis American dollar (CBN, 2012).

In the recent time, the issues regarding exchange rate and its impact on the various economic performance indicators in Nigeria have been a subject of debate among scholars (Aderemi, 2019; Fagbola et al., 2020; Aderemi et al., 2019; Aderemi et al. 2020). Meanwhile, attributing the major cause of exchange rate fluctuations in Nigeria to external debt has been the major concern of scholars and policy makers in the country. Consequently, an attempt to provide an empirical evidence to validate the above assertion by past studies has generated several arguments, which makes literature to be inconclusive about this subject matter. See Kouladoum (2018), Saheed, Sani and Idakwoji (2015), ljeoma (2013), Patrawimolporn (2007), Aderemi (2019) and Aderemi et al. (2019).

In the light of the above, the main aim of the present study is: to examine the nexus between external debt and exchange rate fluctuations in Nigeria, which is the major bone of contention among the scholars and policymakers in the country. The objectives to be achieved in this paper are as follows; the analysis of how external debt, debt service payment, and foreign reserve affect exchange rate fluctuations in Nigeria, and the drawing of relevant conclusions. Despite the availability of many studies on this subject, this study has been carried out to provide a clearer evidence regarding the nexus between external debt and exchange rate fluctuations in Nigeria, using an ARDL technique in which majority of recent studies have not fully explored.

\section{Literature Review}

\subsection{The Debt overhang theory}

Debt overhang theory has been a subject of interest to developing economies because the relationship between external debt and economic growth is complex phenomenon. It has been argued in the theory that the significant principal variable responsible for slowing down the pace of investment is debt overhang. Meanwhile, the subject matter of debt overhang theory is premised on the fact that if the country's repayment ability is less than debt with some probability in the future, the output of the country will likely lack the capacity to sponsor the expected debt service (Krugman, 1989). In the view of the above, local and foreign investors could be discouraged as a result of high tendency of existing foreign creditors to tax some of the returns from investing in the domestic economy. It is worth of note that debt servicing involves interest payments and repayments of principal by the indebted country. However, debt overhang has a wide scope to the extent that its effect do not only manifest in investment in physical capital but also any activity that has to do with incurring of costs upfront with a view to increasing output in the future. These 
activities entail the investment in human capital and in technological advancement which could constitute stronger effects on economic growth over time. The way the indebted country raises the necessary resources required financing external debt service with complementarity of private and public investment is a function of how a debt overhang discourages private investment. For instance, if a government embarks on inflation tax or in a capital levy, this might serve as a discouraging factor to private investment.

In a nut shell debt overhang has been conceptualized as a situation in which the indebted country gets very little benefits from the return on any additional investment due to the obligations of servicing the debt. It is worth of note that the need to service a large amount of external debt could affect performance of economy via some other channels like the crowding out effect as a result of high real interest rate which could worsen the borrowed country and shut-off from foreign credit market. This leads to a decline in investments because of the decrease in available resources for financing investment and macroeconomic conditions.

\subsection{Empirical Literature Review}

This section provides the account of relevant past studies about the relationship between external debt and exchange rate fluctuations. Ogege and Ekpudu (2010) utilized the OLS technique in examining the impact of debt burden on economic growth in Nigeria. The results of the study show that debt stock had a negative impact on the economic growth of the country. Fagbola et al. (2020) carried out a research about nexus between external debts and economic growth in Nigeria using an ARDL to analysis data from 1981 to 2018. The study confirmed that Nigeria experienced a setback in terms of economic growth due to external debt. Aderemi et al. (2020) evaluated the linkage between exchange rate volatility and balance of the Nigerian trade with the application of the ARDL technique of estimation from 1981 to 2016 . The authors submitted that the effect of exchange rate volatility was not favourable to trade balance in Nigeria.

In another study, ljeoma (2013) investigated the relationship between external debt stock, external debt service payment and some selected macroeconomic variables in Nigeria using a linear regression model. The author concluded that there was a significant relationship between debt servicing and gross fixed capital formation in the country. It was further revealed that exchange rate fluctuations affect external debt shock, external debt servicing and economic growth in Nigeria. In a related work, Siok, Cheau and Mohd (2012) examined a nexus between exchange rate and inflation in different three developed and three emerging countries in Asia. The results from the study show that a significant correlation existed between exchange rate movements and inflation those countries in Asia. Similarly, Blessy and Lakshmi (2020) explored ARDL model to investigate the nexus between original Sin, currency depreciation and external debt burden in India from 2001 to 2018. It was discovered from the study that depreciation of the country's currency increased burden of the external debt significantly.

Aderemi et al. (2019) explored a vector error correction model to estimate how foreign capital inflows affected exchange rate volatility in Nigeria from 1990 to 2016. It was concluded from the study that external debt sparked of exchange rate 
volatility in the country. Devereux et al. (2006) discovered that exchange rate depreciation in the foreign exchange market increased external debt in emerging countries. While examining the linkage between external debt and variation in exchange rate from the Romanian economy, Bunescu (2014) used Fisher-Snedecor F-test to estimate the relationship between external debt and exchange rate variation in the Romanian economy. It was discovered from the study that external debt explained the evolution of exchange rate in the study.

Consequently, Alam and Taib (2013) estimated the relationship between external debts, budget deficit, current account deficit and exchange rate depreciation in Debt Trap Countries (DTC) and Non Debt Trap Countries (NDTC) of pacific development countries Asia. The findings the surfaced in the paper posited that there was a positive relationship between external debt, budget deficit, current account deficit and exchange rate depreciation. Meanwhile, the significance of the relationship shows variations in DTC and NDTC. Sene (2004) employed an extension of Obstfeld and Rogoff model to examine how external public debt and equilibrium real exchange rate are related in developing economies. In another perspective, Patrawimolporn (2007) adopted a simple differentiation technique to analyze the relationship between exchange rate, debt, debt services and public debt management in Thailand. The author submitted that exchange rate volatility affects debt services because the exchange rate adjustment led to the savings of a significant amount of debt services.

In another perspective, Mohamed (2005) examined the impact of external debt on economic growth in Sudan from 1978-2002. The author opined that external debt and inflation caused a negative impact on economic growth. Meanwhile, real exports have a significant positive impact on economic growth in the country. Mariano and Delano (2006) adopted a standard neo-classical growth model to examine, external debt, capital accumulation dynamics and economic growth alongside the optimal savings rate within 2000 and 2003 in Philippines. It was concluded from the study that higher ratio of change in interest rate spread to change in debt-to-GDP which reduces welfare in long run in the country. Similarly, Hameed, et al (2008) opined that there was an existence of adverse effect of external debt servicing on labour and capital productivity which was the principal factor that retards economic growth in Pakistan while exploring the dynamic effect of external debt servicing, capital stock and labour force on the economic growth between 1970 and 2003 in Pakistan. While investigating the feedback relationship between short term external debt and GDP growth rate in 27 Latin American and Caribbean countries between 1970 and 2003, Butts (2009) established that the presence of granger causality in thirteen countries. Aderemi et al. (2019) provided an empirical evidence using Vector Error Correction Model to argue that external debt motivated volatility in exchange rate in Nigeria.

However, David et al. (2010) used multiple regression technique to evaluate the relationship between exchange rate fluctuations and performance of manufacturing industry in Nigeria. The results of the regression analysis indicated the presence of a negative relationship between exchange rate volatility and manufacturing sector performance in the country. Adepoju et al. (2007) estimated the relationship between time behaviour of donor agencies in regarding external debt and economic growth in Nigeria spanning from 1962 to 2006. The researchers submitted that the Nigerian economic growth is negatively affected by external debt. 
In another perspective, Aliyu (2011) submitted that appreciation of exchange rate leads to an increment in imports and reduction in exports but depreciation causes an expansion in export and contraction in import. In the same vein, depreciation of exchange rate is likely to lead to a shift from foreign goods to domestic goods, as a result of this, there is a diversion of income from importing countries to exporting countries exporting via a shift in terms of trade and consequently affects economic growth of both the exporting and importing countries. In the same vein, Palić et al. (2018) investigated long run linkage between nominal exchange rate depreciation and external indebtedness in Croatia. The authors submitted that the exchange rate depreciation caused a rise in the external debt burden in the country because most of the country's external liabilities were domiciled in foreign currency.

Furthermore, Asher (2012) concluded that economic growth in Nigeria is positively affected by real exchange rate while examining the link between exchange rate fluctuation and the Nigerian economic growth within the period of $1980-2010$. Carrera and Vergara (2012) examined how real exchange devaluation was caused by the fiscal cost in five Latin American economies. The author posited that accumulation of foreign currency debt could cause fiscal adjustment if devaluation is persistent. Meanwhile, Akpan (2008) investigated the impact of foreign exchange market on economic growth from 1970 to 2003 in Nigeria. The author asserted that there was a presence of a positive relationship between exchange rate and economic growth in the country. In a related work carried out by Hargreaves et al. (2011), it was argued that exchange rate depreciation was a result of external debt in the country, and this could have a significant direct impact on the gross domestic product. Obansa et al. (2013) estimated the nexus between the relationship between exchange rate and economic growth in Nigeria from 1970 to 2010. The paper established that economic growth was strongly impacted by exchange rate and exchange rate liberalization was good to the Nigerian economy because it serves as a promoting factor to economic growth in the country. Azeez et al. (2012) critically examined the relationship between the exchange rate volatility and macroeconomic performance in Nigeria between 1986 and 2010. The study pointed out that exchange rate and Gross Domestic Product were positively related in the country.

Similarly, Aderemi (2019) utilized the technique of DOLS to submit that there is an insignificant inverse linkage between exchange rate volatility and external debt in Nigeria. Furthermore, it could be pinpointed from the above reviewed literature that the studies on external debt and exchange rate fluctuations in Nigeria are ongoing, and the literature is still inconclusive about their nexus in the country.

\section{Methodology}

This study made use of secondary data from 1981 to 2018. Data on external debt, debt service payment and foreign reserve were extracted from Central Bank of Nigeria statistical bulletin (2018). External reserve is measured by total sum of foreign exchange reserve. The values of External debt, Debt service payment and Foreign reserve were converted to the Nigerian currency (Naira) based on the exchange rate of the corresponding year. E-Views software was employed for the running of the data. 


\subsection{Model Specification}

In setting up a model in this study, insight was drawn from some recent studies like Aderemi, (2019), Fagbola et al. (2020), Aderemi et al. (2019), Aderemi et al. (2020) by adapting the model with the elimination of variables that are not relevant to this study.

In a general form, we specify the model as follows;

EXCHR $=F($ ExDebT, DSP, FR $)$

A further step to linearize the adapted model led to model (II) as follows

$$
\text { LnEXCRt }=\beta_{1}+\beta_{2} \text { LnExDebTt }+\beta_{3} L n D S P t+\beta_{4} F R t+\mu_{i}
$$

However, the variables could be explained thus; EXCR represents exchange rate fluctuations. ExDebT is used to denote external debt. DSP stands for debt service payment. And FR represents foreign reserve, while $\mu$ is error term which is assumed to be serially uncorrelated. $t$ is period of analysis (1981-2018). The a priori expectations are as follows $\beta 2$ and $\beta_{3}>0, \beta 4<0$

\subsection{ARDL Model Specification}

According to Pesaran et al. (2001), Pesaran and Pesaran (1997), an autoregressive distributed lag model is considered as an appropriate technique for this study because findings from unit root test indicated that the orders of integration of the variables are. I(1) and I(0). As thus, ARDL model could be specified as follows:

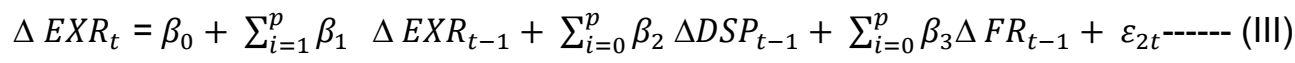

\subsection{Result and Discussion}

Table 1: Descriptive Statistics of Annual Data Series (1981-2018)

\begin{tabular}{|l|l|l|l|l|}
\hline Descriptive Statistics & LDSP & LEXCHR & LExDebT & LFR \\
\hline Mean & 10.76358 & 3.293779 & 6.077476 & 11.99862 \\
\hline Median & 10.74401 & 3.811329 & 6.437942 & 11.43748 \\
\hline Maximum & 15.32974 & 5.535333 & 8.495003 & 18.04121 \\
\hline Minimum & 6.996041 & -0.494255 & 0.846383 & 8.608806 \\
\hline Std. Deviation & 1.953560 & 1.947659 & 1.932532 & 2.220557 \\
\hline Skewness & 0.059060 & -0.735476 & -1.050327 & 0.830079 \\
\hline Kurtosis & 2.860318 & 2.202196 & 3.407236 & 3.201404 \\
\hline Jargue-Bera & 0.050195 & 4.200288 & 6.867885 & 4.195028 \\
\hline Probability & 0.975215 & 0.122439 & 0.032260 & 0.122761 \\
\hline Sum & 387.4888 & 118.5761 & 218.7891 & 431.9503 \\
\hline Sum. Sq. Deviation & 133.5738 & 132.7681 & 130.7138 & 172.5806 \\
\hline Observation & 38 & 38 & 38 & 38 \\
\hline
\end{tabular}

Source: Authors' Computation (2020) 
The descriptive statistics of the dataset is presented in the above table to verify the normal distribution of the dataset for further econometric analysis. As shown in the table above, the data is normally distributed because the mean and median values of all the adopted variables are almost the same. The normal distribution of dataset is symmetrical when the mean, modal and median values of the dataset are identical (Karmel and Polasek 1980). Furthermore, the other useful information which also attests to the normal distribution of the dataset is shown in the values of minimum and maximum; and how the sample is distributed measured through the values of skewness, kurtosis and Jaque-Bera statistics.

Table 2: Unit Root Test

\begin{tabular}{|c|c|c|c|c|c|c|}
\hline \multirow[t]{2}{*}{ Variables } & \multicolumn{3}{|c|}{ ADF Test } & \multicolumn{3}{|c|}{ PP Test } \\
\hline & Level & $1^{\text {st }}$ Diff. & Remarks & Level & $1^{\text {st }}$ Diff. & Remarks \\
\hline LDSP & $-2.981038^{\star *}$ & & $\mathrm{I}(0)$ & $-2.948404^{\star *}$ & & $I(0)$ \\
\hline LEXCHR & $-2.948404^{\star *}$ & $-2.951125^{\star *}$ & I(1) & $-2.948404^{\star *}$ & $-2.951125^{\star *}$ & I(1) \\
\hline LExDebT & $-2.951125^{\star \star}$ & $-2.951125^{\star *}$ & I(1) & $-2.948404^{* *}$ & $-2.951125^{\star *}$ & $\mathrm{I}(1)$ \\
\hline LFR & $-2.960411^{\star \star}$ & $-2.954021^{\star *}$ & I(1) & $-2.948404^{* *}$ & $-2.951125^{\star \star}$ & I(1) \\
\hline
\end{tabular}

Source: Authors' Computation (2020)

** \%5 level

The data for this work were subjected to a unit root test through the standard Augmented Dickey-Fuller (ADF) and Phillips-Perron (PP) tests. The estimated results reported as shown in table 2 clearly proved that the data on exchange rate, external debt and foreign reserve are stationary after first differencing. This implies that these data are said to possess a unit root. However, data on debt service payment is stationary at a level. This indicates that the data does not have a unit root. In a nutshell, the data employed in this study comprise the mixture of $\mathrm{I}(1)$ and $\mathrm{I}(0)$ data.

Table 3: ARDL Bounds Test

Sample: 19852018

Included observations: 35

Null Hypothesis: No long-run relationships exist

\begin{tabular}{lll}
\hline \hline Test Statistic & Value & $\mathrm{K}$ \\
\hline \hline F-statistic & 2.058660 & 3 \\
\hline \hline
\end{tabular}

Critical Value Bounds

\begin{tabular}{lcc}
\hline \hline Significance & 10 Bound & I1 Bound \\
\hline \hline $5 \%$ & 3.23 & 4.35 \\
\hline \hline
\end{tabular}

Source: Authors' Computation (2020) 
The estimated result of Bound Test is shown in table 3 with a view to establishing the existence or otherwise of a long run relationship among the variables of interest in this work. From the above, it could be established that the Null hypothesis of no long run relationship could not be rejected because the FStatistic value is lower than the upper and lower Critical Value Bounds at all level of significance. This shows that there is no cointegrating relationship among the variables in the model.

Table 4: Short Run Relationship Dependent Variable: EXCH

\begin{tabular}{|c|l|l|l|}
\hline Variable & Coefficient & t-statistics & P-value \\
\hline LEXCH(-1) & $-0.353840^{*}$ & 1.517105 & 0.1487 \\
\hline LEXCH(-2) & $-0.416136^{* *}$ & 2.214302 & 0.0417 \\
\hline LExdebT(-1) & $0.500641^{* * *}$ & 5.879661 & 0.0000 \\
\hline LExdebT(-2) & $0.212419^{* *}$ & 2.054453 & 0.0566 \\
\hline LFR(-1) & $0.208740^{* *}$ & 2.611069 & 0.0189 \\
\hline LFR(-2) & $0.169710^{* *}$ & 2.316026 & 0.0342 \\
\hline LDSP(-1) & $0.221351^{* *}$ & 3.195151 & 0.0056 \\
\hline C & 0.074763 & 0.111878 & 0.9123 \\
\hline
\end{tabular}

Source: Authors' Computation (2020) ${ }^{*}$ Significant at $10 \%,{ }^{* *}$ Significant at $5 \%,{ }^{* * *}$ Significant at $1 \%$

The ARDL result of the short run relationship between external debt and exchange rate fluctuation is presented in the above table. All the explanatory variables have the expected sign except foreign reserve. External debt has a significant positive relationship with exchange rate fluctuations at lag 1 and 2 . At lag 2 , a unit change in external debt causes an increment in exchange rate fluctuations by $0.21 \%$. This finding is validated by the submission of Saheed et al. (2015) and Alam and Taib (2003) despite adoption of different methodology. Kouladoum (2018) and Blessy and Lakshmi (2020) also asserted the same conclusion in a similar studies in Chad and India respectively. This finding is also in tandem with conclusions of Devereux et al. (2006) in emerging economies and Hargreaves et al. (2011) in New Zealand concurrently. Similarly, debt service payment and exchange rate fluctuations have a significant positive relationship with each other in Nigeria. At lag 1 , a unit change in debt service payment increases exchange rate fluctuations by $3.2 \%$ in the country. This result is consistent with the findings of Saheed et al. (2015) and Patrawimolporn (2007) but contradicts the submission of Kouladoum (2018). However, foreign reserve and exchange rate fluctuations have a significant direct relationship in the country. The reason for this positive might be as a result of the over dependence of the country on foreign goods.

\subsection{Conclusion and Discussion}

This study investigates the short run relationship between external debt and exchange rate fluctuations in Nigeria over the period of 1981 to 2018. Consequently, the summary of the major findings in this study are summarized as follows: external debt, debt payment service and foreign reserve have a significant positive impact on exchange rate fluctuations in the short run in Nigeria. Furthermore, based on the 
findings that originated from this work, this study make the following recommendations for the policy makers in the country that external debt as a means of financing budget deficit should be minimized if not totally discouraged in Nigeria because its servicing in particular and repayment put pressure on foreign exchange market in the short run and thereby leads to exchange rate fluctuations in terms of depreciation of naira in the country. Also, country's foreign reserve should be strengthened through the implementation of aggressive export promotion policy in Nigeria.

Finally, it is instructive to stress that a limitation to this work lies in its inability to assess the parallel market exchange rate situations in the country. A list of both practical and theoretical implications of this work is embedded in discouraging deficit budget financing in Nigeria. Therefore, it is imperative to develop further studies considering how external debt affects parallel exchange rate situations in the country.

\section{References}

Aderemi T.A., Ogunleye G.A., Abalaba B.P., Owolabi, O.O. (2020) Exchange Rate Volatility and Trade Balance in Nigeria: Bound Test and ARDL Approach, Euro Economica, 39(1), 7-16

Aderemi, T.A. (2019) Exchange Rate Volatility and Foreign Capital Inflows in Nigeria (1990-2016), Cointegration, DOLS and Granger Causality Approach, Management Studies and Economic Systems, 4(2), 161-170

Aderemi T. A., Akinbode S. O., Omogboye M.A., Fagbola L. O. (2019) Exchange Rate Volatility and Foreign Capital Inflows in Nigeria: A Vector Error Correction Model Approach, Acta Universitatis Danubius. CEconomica, 15(5), 34-43

Akpan, P.L. (2008) Foreign exchange market and economic growth in an emerging petroleum based economy: Evidence from Nigeria (1970-2003), African Economic and Business Review, 6 (2), 46-58.

Adepeju A. A., Salau A. S., Obayelu, A. E. (2007) the effects of External Debt Management on Sustainable Economic Growth and Development: Lessons from Nigeria, Munich Personal Respective (MPRA) Paper No.2147

Alam N., Taib F. (2013) An Investigation of the Relationship of External Public Debt with Budget Deficit, Current Account Deficit and Exchange Rate Depreciation in Debt Trap and Non-Debt Trap Countries, European Scientific Journal, 9 (22), 2331

Aliyu, S.R.U. (2011) Impact of oil price shock and exchange rate volatility on economic growth Nigeria: An empirical investigation, Research Journal of International Studies

Aluko F., Arowolo D. (2010) Foreign Aid, the Third World's Debt Crisis and the Implication for Economic Development: The Nigeria Experience, African Journal of Political Science and International Relations, 4(4), 120-127

Asher O.J. (2012) The Impact of Exchange rate Fluctuation on the Nigeria Economic Growth $(1980$ - 2010). Unpublished B.sc Thesis of Caritas University Emene, Enugu State, Nigeria

Ayadi, F. S., Ayadi F. O. (2008) the impact of external debt in economic growth: A comparative study of Nigeria and South Africa, Journal of Sustainable Development in Africa, 10 (3), 234-264. 
Azeez B.A.; Kolapo F.T., Ajayi L.B. (2012) Effect of Exchange rate Volatility on Macroeconomic Performance in Nigeria, Interdisciplinary Journal of Contemporary Research in Business. 4 (1), 149-155

Blessy A., Lakshmi K. (2020) Original Sin, Currency Depreciation and External Debt Burden: Evidence from India, International Journal of Economics and Financial Issues, 10(3), 58-68

Bunescu L. (2014) The Impact of External Debt on Exchange Rate Variation in Romania, Economics and Sociology, 7(3), 104-115

Calvo G.A., Reinhart C. M. (2002) Fear of floating, Quarterly Journal of Economics. 117 (2), 379-408

Carrera C.M., Vergara, R. (2012) Fiscal sustainability: The impact of real exchange rate shocks on debt valuation, interest rates and GDP growth, World Development, 40(9), 1762-1783

CBN (2012) Annual Statistical Bulletin.

David U., Ameh A. 2010. The Effect of exchange rate fluctuations on Nigeria manufacturing sector, African Journal of Business Management, 4 (14), 29942998

Devereux M.B., Lane P.R., Xu J. (2006) Exchange rates and monetary policy in emerging market economies, The Economic Journal, 116(511), 478-506.

Dickey, D.A., Fuller, W.A. (1979) Distribution of the Estimators for Autoregressive Time Series with a Unit Root, Journal of the American Statistical Association, 74, 427-431

Fagbola L. O., Sokunbi, G. M., Aderemi T. A., Adebayo, A. G. (2020) External Debt and Economic Growth in Nigeria: An Implication for Debt Overhang Theory, Journal of Economics, Law and Politics, 7(2), 29-39

Hameed A., Ashraf H., Claudlary M. A. (2008) External Debt and its Impact on Economic and Business Growth in Pakistan, International Research Journal of Finance and Economics Issue 20

Ijeoma N.B. (2013) an Empirical Analysis of the Impact of Debt on the Nigerian Economy, International Journal of Arts and Humanities, 2 (7), 165-191

Jean-Claude Kouladoum (2018) External debts and real exchange rates in developing countries: evidence from Chad. Online at https://mpra.ub.unimuenchen.de/88440/ MPRA Paper No. 88440, posted 19 August 2018 02:32 UTC

Hargreaves, D., Watson, E. (2011) sudden stops, external debt and the exchange rate, Reserve bank of New Zealand: Bulletin, 74(4), 17-27

Karmel P. H., Polasek M, (1980). Applied statistics for economists. Pitman Publishing

Krugman, P. (1989) Market Based Debt reduction Schemes. NBER Working Paper No. 16827, February 2011

Obansa S.A.J., Okoroafor O.K.D., Aluko O.O., Millicent E. (2013) Perceived relationship between exchange rate, interest rate and economic growth in Nigeria: 1970-2010, American Journal of Humanities and Social Sciences, 1 (3), 116-124

Ogege S. A., Ekpudu J.E. (2010) The Effect of Debt Burden on the Nigerian Economy, Journal of Research in National Development, 8 (2), 13-21 
Palić I., Banić F., Matić L. (2018) The analysis of the impact of depreciation on external debt in long run: Evidence From Croatia, Interdisciplinary Description of Complex Systems, 16(1), 186-193.

Patrawimolporn P. (2007) Effect of Exchange Rate on Debt, Debt Services and Public Debt Management in Thailand in the 1980s, Asian Economic Journal, 5,3

Pesaran M. H., Shin Y., Smith R. J. (2001) Bounds testing approaches to the analysis of level relationships, Journal of Applied Econometrics, 16, 289-326

Pesaran M., Pesaran B. (1997) Microfit 4.0 (windows version). New York: Oxford University Press Inc

Phillips P. C., Perron P. (1988) Testing for a unit root in time series regression, Biometrika, 75, 335-346

PNUD (2011) Rapport mondial sur le développement humain.

Saheed Z. S., Sani I. E. Idakwoji B. O. (2015) Impact of Public External Debt on Exchange Rate in Nigeria, European Journal of Business and Management, 7(21), 55-59

Semenitari I. (2005) The Road to Debt Relief. Tell Magazine, 29, July 19, 38

Sene B. (2004) The Impact of Debt Overhang on Equilibrium Real Exchange Rate in Developing Countries: A Theoretical Model. EURISCO Working Paper, No. 0417

Siok K. S., Cheau P. O., Mohd T.I. (2012) Investigating the Relationship between Exchange Rate and Inflation Targeting, Applied Mathematical Sciences, 6(32),15711583 